\title{
A Study on Human Resource in a General Directorate in the Indonesia Ministry of Education and Culture
}

\author{
Yustinus R. Dandono ${ }^{1 *}$, Yohanes Parmin ${ }^{1}$, Albiansyah Albiansyah ${ }^{1}$, Johan Maulana $^{1}$ \\ ${ }^{I}$ STIE Bhakti Pembangunan, Jakarta Selatan - 12270, Indonesia \\ *Corresponding author. Email: y_rawi_d@yahoo.com
}

\begin{abstract}
The performance of BPSDMPK (Badan Pengembangan Sumber Daya Manusia - Pendidikan dan Kebudayaan - Human Resource Development and Education Quality Assurance Agency) and PMP (Penjaminan Mutu Pendidikan - Quality Assurance in Education) of Indonesia Ministry of Education and Culture in 2017 showed that between the reality in the field and the target desired to be achieved is not in accordance with expectation. This causal research was aimed at finding the information concerning the possibility of managerial effectiveness affected by human resource development, organizational culture, employee competence, and organizational commitment. This research used a survey method, in which the data was analyzed using path analysis after all variables had been put into a correlation matrix. The research results revealed that: (1) Human resource development has a direct and positive effect on managerial effectiveness; (2) Organizational culture has a direct and positive effect on managerial effectiveness; (3) Employee competence has a direct and positive effect on managerial effectiveness; (4) Organizational commitment has a direct and positive effect on managerial effectiveness; (5) Human resource development has a direct and positive effect on employee competence; (6) Organizational culture has a direct and positive effect on employee competence; (7) Human resource development has a direct and positive effect on organizational commitment; (8) Organizational culture has a direct and positive effect on organizational commitment; and (9) Human resource development has a direct and positive effect on organizational culture.
\end{abstract}

Keywords: Managerial effectiveness, human resource development, organizational culture, employee competence, organizational commitment

\section{INTRODUCTION}

Based on Government Institution Performance Report of BPSDMPK (Badan Pengembangan Sumber Daya Manusia - Pendidikan dan Kebudayaan - Human Resource Development and Education Quality Assurance Agency) and PMP (Penjaminan Mutu Pendidikan - Quality Assurance in Education) of Indonesia Ministry of Education and Culture in 2017, it can be seen that between the reality in the field and the target desired to be achieved is not in accordance with expectation. From $80 \%$ HR of IV-Echelon, only $50 \%$ of the staffs have performance according to standard achievement in the planning of Government Institution Performance Report (LAKIP). This becomes a problem that makes the researchers carried out further research.

The problem faced by BPSDMPK and PMP Agencies, which by the Regulation of Minister of Education and Culture was changed into General Directorate of Teacher and Educator (GDTE) as the institution in-charge to handle HR education development program, even in concept, the management has been done starting from planning-up to conducting performance evaluation.

Organization is a container to manage a wide-range of activities directed to achieve the organizational objectives
[1]. The implementation of activities in organization is done by human beings who are acting as actors in the relevant organization. In order for an organization to run smoothly and effectively, it needs people who have certain abilities in accordance with their respective duty, and equally important is the presence of a person who can be a role model for all people to bring the organization or institution to achieve its goals that have been determined, namely a figure of leader [2]. Such person will bring quality instructions that allows the organization to run effectively [3].

Current study on managerial behavior is closely related to the effective management practice and leadership practice [4]. The research results reported that several qualitative cases and manager exploration across sectors towards managerial staff of private, government, and organization of the three sectors are deemed effective towards managerial behavior [5]. Based on an empirical finding, it was obtained that in the previous nine replication studies, the comparison was based on the analysis which causes the taxonomy to be deducted from the perceived managerial effectiveness towards leadership [6]. The research result shows that managerial effectiveness is very important to manage an organization that needs qualified and competitive staffs in developing human resources [7]. Referring to the explanation in the background, the research questions can be 
formulated as follows:

RQ1: Is there significant effect of HR development on managerial effectiveness?, RQ2: Is there significant effect of organizational culture on managerial effectiveness?, RQ3: Is there significant effect of staff competency on managerial effectiveness?, RQ4: Is there significant effect of organizational commitment on managerial effectiveness?, RQ5: Is there significant effect of HR development on staff competency?, RQ6: Is there significant effect of organizational culture on staff competency?, RQ7:Is there significant effect of HR development on organizational commitment?, RQ8: Is there significant effect of organizational culture on organizational commitment?, RQ9: Is there significant effect of HR development on organizational culture?

\section{EXPERIMENTAL METHOD}

\subsection{Data Collection}

This research used a survey with quantitative approach, with 151 respondents acquired by using the purposive-sampling technique in Jakarta. This quantitative approach used a pathanalysis technique. This path analysis was used to test the direct and indirect effects among the variables being studied, namely: HR development, organizational culture, staff competency, and organization commitment towards managerial effectiveness among 151 persons of IV-Echelon officials in the environment of General Directorate of Teacher and Educator of Indonesia Ministry of Education and Culture. This data was used to test our research framework.

\subsection{Tool and Methods}

The path-diagram technique was used to detect the relationship among all variables. The path-diagram model was performed by using AMOS Program version 24.0.

\subsection{Proposed Hypothesis}

Based on the framework of thinking and research questions, a causal-research theoretical model was prepared as shown in Figure 1 below:

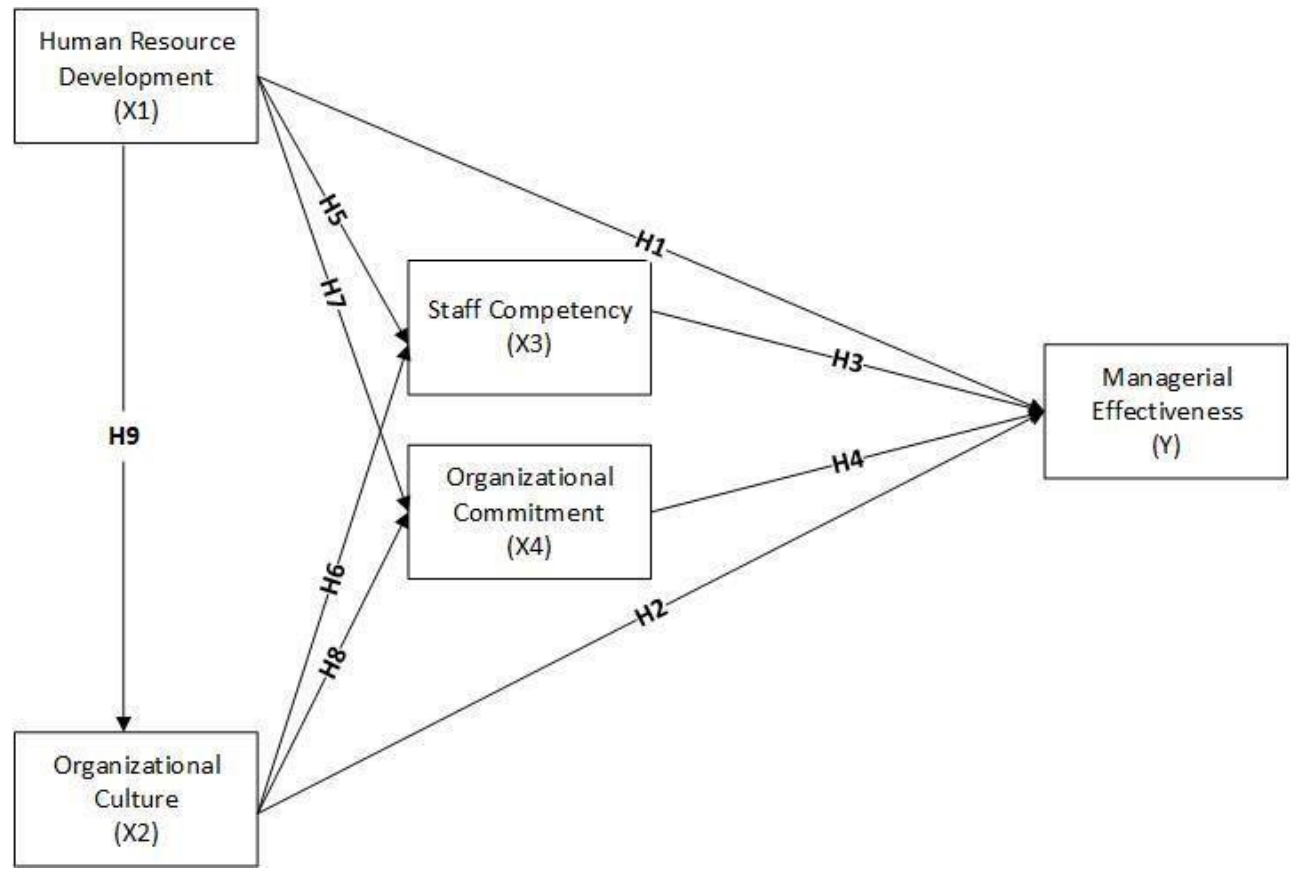

Figure 1 Research Framework

The hypotheses developed in this research are shown in

Table 1.

Table 1 Research Hypothesis

\begin{tabular}{|c|c|}
\hline Number & Hypothesis \\
\hline $\mathrm{H}_{1}$ & HR Development directly and positively affects Managerial Effectiveness [3] [5] [6] \\
\hline $\mathrm{H}_{2}$ & Organizational Culture directly and positively affects Managerial Effectiveness [4] \\
\hline $\mathrm{H}_{3}$ & Staff Competency directly and positively affects Managerial Effectiveness [7] \\
\hline $\mathrm{H}_{4}$ & Organizational Commitment directly and positively affects Managerial Effectiveness [8] \\
\hline
\end{tabular}




\begin{tabular}{|l|l|}
\hline $\mathrm{H}_{5}$ & HR Development directly and positively affects Staff Competency [5] [6] \\
\hline $\mathrm{H}_{6}$ & Organizational Culture directly and positively affects Staff Competency [9] [11] [12] \\
\hline $\mathrm{H}_{7}$ & HR Development directly and positively affects Organizational Commitment [3] [6] \\
\hline $\mathrm{H}_{8}$ & Organizational Culture directly and positively affects Organizational Commitment [10] [11] \\
\hline $\mathrm{H}_{9}$ & HR Development directly and positively affects Organizational Culture [9] [11] \\
\hline
\end{tabular}

\section{RESULTS}

The most important component in performing a structural model is the value of path coefficient. A path coefficient indicates the direct effect of a variable assumed to be a cause on another variable assumed to be an effect. The path coefficient is used to test the hypothesis that has been prepared. The results of the structural-paths obtained are as follows:

1. $\mathrm{H}_{1}$ has a path-coefficient of 0.209 with t-statistics of 2.955 and t-table $(0.05 ; 151)$ of 1.96 . Thus, t-statistics (2.955) > t-table (1.96), so it can be concluded that HR development has a direct and positive effect on managerial effectiveness.

2. $\mathrm{H}_{2}$ has a path-coefficient of 0.256 with t-statistics of 3.844 and t-table $(0.05 ; 151)$ of 1.96 . Thus, t-statistics $(3.844)>$ t-table $(1.96)$, so it can be concluded that organizational culture has a direct and positive effect on managerial effectiveness.

3. $\mathrm{H}_{3}$ has a path-coefficient of 0.196 with t-statistics of 2.556 and t-table $(0.05 ; 151)$ of 1.96 . Thus, t-statistics $(2.556)>$ t-table $(1.96)$, so it can be concluded that staff competency has a direct and positive effect on managerial effectiveness.

4. $\mathrm{H}_{4}$ has a path-coefficient of 0.305 with t-statistics of 4.113 and t-table $(0.05 ; 151)$ of 1.96 . Thus, t-statistics (4.113) > t-table (1.96), so it can be concluded that organizational commitment has a direct and positive effect on managerial effectiveness.

5. $\mathrm{H}_{5}$ has a path-coefficient of 0.484 with t-statistics of 7.094 and t-table $(0.05 ; 151)$ of 1.96 . Thus, t-statistics (7.094) > t-table (1.96), so it can be concluded that HR development has a direct and positive effect on staff competency.

6. $\mathrm{H}_{6}$ has a path-coefficient of 0.397 with t-statistics of 5.812 and t-table $(0.05 ; 151)$ of 1.96 . Thus, t-statistics $(5.812)>$ t-table (1.96), so it can be concluded that organizational culture has a direct and positive effect on staff competency.

7. $\mathrm{H}_{7}$ has a path-coefficient of 0.486 with t-statistics of 6.913 and t-table $(0.05 ; 151)$ of 1.96 . Thus, t-statistics (6.913) > t-table (1.96), so it can be concluded that HR development has a direct and positive effect on organizational commitment.

8. $\mathrm{H}_{8}$ has a path-coefficient of 0.381 with t-statistics of 5.415 and t-table $(0.05 ; 151)$ of 1.96 . Thus, t-statistics $(5.415)>$ t-table $(1.96)$, so it can be concluded that organizational culture has a direct and positive effect on organizational commitment.

9. $\mathrm{H}_{9}$ has a path-coefficient of 0.720 with t-statistics of 12.676 and t-table $(0.05 ; 151)$ of 1.96 . Thus, t-statistics (12.676) > t-table (1.96), so it can be concluded that HR development has a direct and positive effect on organizational culture.

The summary of the results of hypotheses testing can be seen in Figure 2 below.

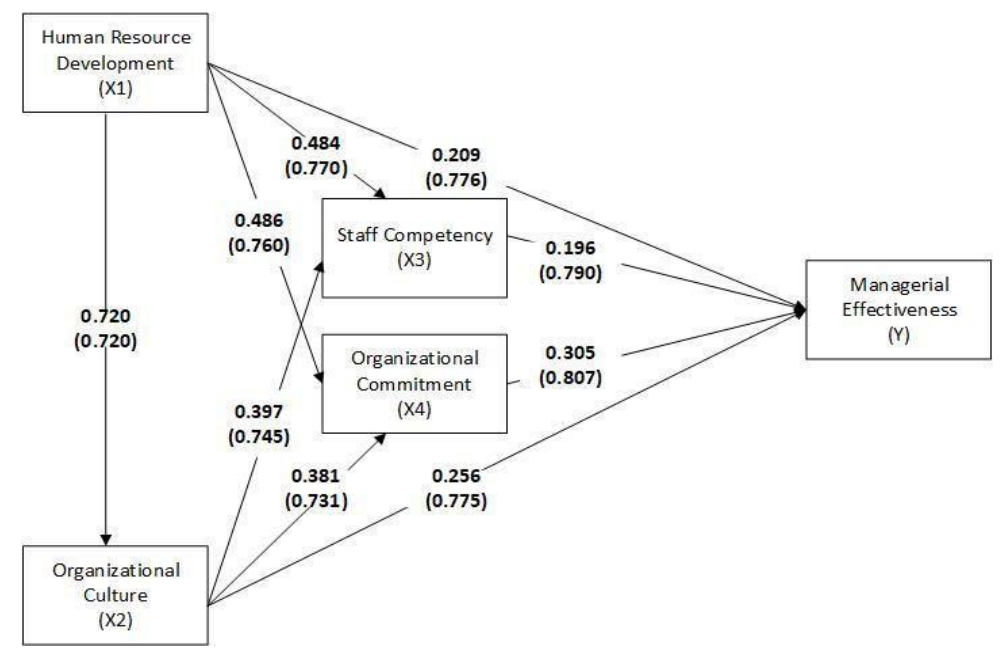

Figure 2 The Results of Hypothesis Testing Source: Path Analysis Results, 2020 


\section{DISCUSSIONS}

Based on the results of hypotheses testing and path analyses, it is shown that all the hypotheses proposed were accepted, which means that all paths have positive and significant effects, both directly and indirectly, among the independent and dependent variables. Therefore, based on the hypotheses test results using multiple-regression method, data analysis resulted in some interesting findings:

First, we know that there is a direct and positive effect of HR Development $\left(\mathrm{X}_{1}\right)$ on Managerial Effectiveness (Y). This result confirms that HR development must be conducted by the organization to facilitate its goal achievement. HR development is actually rooted on the management concept. Management is a work-related activities and coordination process in an organization to make the work to be accomplished effectively and efficiently by and through other persons. Effectiveness refers to completing the activities so that the organizational target can be achieved and measured. Efficiency refers to obtaining the largest output by using the lowest input. The forementioned research results can be interpreted that HR development highly affects the organizational goal, or in other word, HR development can affect managerial effectiveness [5]. Effectiveness can describe all cycles of input, process, and output that refer to effectiveness of an organization, program, or activity, which states that the extent of goal (quality, quantity, and time) is achieved [11]. Therefore, an organization, program, and activity are effective, if the desired goal or target can be achieved in accordance with the plan and can generate the desired effect, result, or benefit. Second, based on the result of the second hypothesis $\left(\mathrm{H}_{2}\right)$ testing, there is a direct and positive effect of Organizational Culture $\left(\mathrm{X}_{2}\right)$ on Managerial Effectiveness (Y). This finding confirms that organizational culture is one of the most important elements in an organization that directs the behavior that is proper, binding, and motivating each individual within. The culture is stable and difficult to change as it reflects the learning accumulation of a group in the way they think, feel, and convince the world that culture can create a success to the organization. There is no right or wrong culture, there is no better or worse culture, except in the relation to the way an organization acts and what environment that supports the organization [10].

Third, based on the result of the third hypothesis $\left(\mathrm{H}_{3}\right)$ testing, there are a direct and positive effect of Staff Competency $\left(\mathrm{X}_{3}\right)$ on Managerial Effectiveness $(\mathrm{Y})$. This finding result confirms that competency is becomes the basic ability that must be possessed by a person to produce something expected by the organization. If the person is a staff, then the person must be able to give real contribution to his / her work, the competency that must be owned includes skill, prowess, and capability in ICT.

Forth, based on the result of the fourth hypothesis $\left(\mathrm{H}_{4}\right)$ testing, there is a direct and positive effect of Organizational Commitment $\left(\mathrm{X}_{4}\right)$ on Managerial Effectiveness (Y). This finding confirms that commitment is the responsibility of a person to his / her organization. The concerned responsibility is the involvement of an organization member in realizing the organizational goal. Organizational commitment is in form of high loyalty and involvement to the organization, A staff with high level of organizational commitment will involve himself / herself to the organization and cooperate on behalf of the organization [17].

Fifth, based on result of the fifth hypothesis $\left(\mathrm{H}_{5}\right)$ testing, there is a direct and positive effect of HR Development $\left(\mathrm{X}_{1}\right)$ on Staff Competency $\left(\mathrm{X}_{3}\right)$. This finding confirms that HR development for staffs is a learning process and systematic training to improve their competency and performance in the work currently and to prepare them for a future role and responsibility [3]. HR development is also an effective way to overcome several challenges faced by most largeorganizations. HR development currently can be seen as the occurrence of capability growth that much exceeds anything demanded in a work, namely to improve the staffs' ability in handling various kinds of assignment [6].

Sixth, based on the result of the sixth hypothesis $\left(\mathrm{H}_{6}\right)$ testing, there is a direct and positive effect of Organizational Culture $\left(\mathrm{X}_{2}\right)$ on Staff Competency $\left(\mathrm{X}_{3}\right)$.

These findings indicate that a good organizational culture will create a work atmosphere that encourages each individual to improve their competence for the achievement of organizational goals. Competence is in the form of mastery of knowledge, skills, values, and attitudes that lead to performance.

Seventh, based on the result of the seventh hypothesis $\left(\mathrm{H}_{7}\right)$ testing, there is a direct and positive effect of HR Development $\left(\mathrm{X}_{1}\right)$ on Organizational Commitment $\left(\mathrm{X}_{4}\right)$. These findings confirm that the development of human resources plays an active role in building a strong organizational commitment towards an era full of challenges. Therefore, HR development activities cannot be ignored, especially in strengthening organizational commitment.

Eighth, there is a direct and positive effect of Organizational Culture $\left(\mathrm{X}_{2}\right)$ on Organizational Commitment $\left(\mathrm{X}_{4}\right)$. This finding confirms that organizational commitment is a binding of a person to his / her organization, which can be seen from trust to the organization, loyalty to the organization, and active participation to any problem occurs in the organization [11].

Ninth, there is a direct and positive effect of $\mathrm{HR}$ Development $\left(\mathrm{X}_{1}\right)$ on Organizational Culture $\left(\mathrm{X}_{2}\right)$. This finding confirms that human-resource development is closely related to the intellectual ability needed to carry out a better work. Human-Resource development is grounded on the fact that each manpower needs better knowledge, expertise, and skill. Development also helps the staffs to prepare themselves in facing the work or title change caused by new technology or new product [12].

\section{CONCLUSION AND IMPLICATION}

Based on the results of data analysis and discussions on the research results, then from the findings of this research results, it can be concluded as follows: (1) HR Development has a direct and positive effect on Managerial Effectiveness; 
(2) Organizational Culture has a direct and positive effect on Managerial Effectiveness; (3) Staff Competency has a direct and positive effect on Managerial Effectiveness; (4) Organizational Commitment has a direct and positive effect on Managerial Effectiveness; (5) HR Development has a direct and positive effect on Staff Competency; (6) Organizational Culture has a direct and positive effect on Staff Competency; (7) HR Development has a direct and positive effect on Organizational Commitment; (8) Organizational Culture has a direct and positive effect on Organizational Commitment; (9) HR Development has a direct and positive effect on Organizational Culture. The Implication of this research results are as follows: (1) HR development improvement will increase managerial effectiveness. The implication is that managerial effectiveness can be increased by improving the HR development; (2) Organizational culture improvement will increase managerial effectiveness. The implication is that managerial effectiveness can be increased by improving the organizational culture; (3) Staff competency improvement will increase managerial effectiveness. The implication is that managerial effectiveness can be increased by improving the staff competency; (5) Organizational commitment improvement will increase managerial effectiveness. The implication is that managerial effectiveness can be increased by improving the organizational commitment; (6) HR development improvement will improve staff competency. The implication is that staff competency can be increased by improving the HR development; (7) Organizational culture improvement will increase organizational commitment. The implication is that organizational commitment can be increased by improving the organizational culture.

\section{REFERENCES}

[1] Gberevbie D. E., The Impact of Human Resource Development and Organizational Commitment on Financial Sector Employees in Nigeria, Scientific Annuals of the Alexandru Ioan Cuza, University of Iasi Economic Sciences, 2012 pp.36.

[2] Zaim H., "Analyzing the Effects of Individual Competencies on Performance: A Field Study in Services Industries in Turkey" Journal of Global Strategic Management. Vol. 7. N. 2. 2013-December. 67-77. DOI: 10.20460/JGSM.2013715668.

[3] Kelepile K., "Impact of Organizational Culture on Productivity and Quality Management: A Case Study in Diamond Operations Unit, DTC Botswana”. International Journal of Research in Business Studies and Management Volume 2, Issue 9, September 2015, pp. 35-45 ISSN 2394-5923 (Print) \& ISSN 2394-5931 (Online).

[4] Ahmad M. S. "Impact of Organizational Culture on Performance Management Practices in Pakistan",
Business Intelligence Journal, 2012, Vol.5 No.1. [5] Deshmukh, Mahesh, and Godse, Manish, Organizational Culture and Competencies, Journal of Knowledge Management, CSI Communication Vol. 36, Issue No. 3, 2012, pp.35.

[6] Ahmed M. \& Shafiq S., "The Impact of Organizational Culture on Organizational Performance: A Case Study of Telecom Sector". Global Journal of Management and Business Research: An Administration and Management, Volume 14 Issue 3 Version 1.0, Year 2014. Type: Double Blind Peer Reviewed International Research Journal Publisher: Global Journals Inc. (USA) Online ISSN: 2249-4588 \& Print ISSN: 0975-5853.

[7] Ng'ang'a M. J., “The Impact of Organizational Culture on Performance of Educational Institutions". International Journal of Business and Social Science, Vol. 3, No. 8, April 2012.

[8] Ahmad M. S., "Impact of Organizational Culture on Performance Management Practices in Pakistan". Business Intelligence Journal, Vol.5, No.1, 2012.

[9] Apte N., "Managerial Effectiveness: Make and Share Best Bets about Where the World is Going", DMIETR International Journal on Human Resource Management. 2012, Vol.1, pp. 66.

[10] Fernández R., "Alfred Marshall Lecture Women, Work, And Culture" New York University. Journal of the European Economic Association April-May 2007 5(2-3):305-332 by the European Economic Association E-mail address: raquel.fernandez@nyu.edu (Accessed 28 May 2015)

[11] Murbijanto R. E., "Analysis of the Effect of Work Competence and Physical Work Environment on Employee Performance" (A Study of Employees of the Bekasi Regency Manpower Office), Dissertation: Diponegoro University, 2013.

[12] Snell S. J., Tonidandel S., Braddy P. W., and Fleenor J. W., The relative importance of political skill dimensions for predicting managerial effectiveness, USA European Journal of Work and Organizational Psychology, 2014 Vol. 23, No. 6, pp. 915-929, http://dx.doi.org/10.1080/1359432X.2013.817557 (Accessed 28 May 2015). 